\title{
Baptism and the interpretation of early Christian art
}

\author{
HF Stander
}

\begin{abstract}
Baptism and the interpretation of early Christian art

The aim of this article is to stress the necessity of interpreting early Christian art in its context and with due respect to its deep structure or primary notion. It often happens that scholars base their arguments on the superficial features of a work of art, but they fail to understand the notion which these features convey. This will be illustrated by examples of baptismal scenes. It will be shown how these scenes of art are misused and misinterpreted by modern scholars because the above-mentioned principles are disregarded.
\end{abstract}

Though the term 'text' is generally used to refer to a written form of communication, it can consist of any sign or group of signs (cf Louw 1984: 18). As such the term 'text' can also be used to refer to a work of art. Most people are fully aware of the danger of interpreting a small unit in a linguistic text without paying proper attention to its whole context. However, when it comes to an art text, people are often less careful. They often build their arguments on a minor aspect of a depiction, while ignoring its wider context.

Moreover, the actual meaning of any written communication lies in its notion, linguistically called its deep structure. In order to convey this notion, the original writer selects, orders and arranges his material around this notion. One should realise, however, that the way and manner in which a notion is expressed (= surface structure), is always secondary to its deep structure (cf Louw 1973). But these linguistic principles can also be applied to an art text. In a work of art too, there is a deep structure or a notion which the artist wants to express. He can do this in various ways (= surface structure), but again the manner is secondary to the basic meaning. It often happens that scholars base their arguments on the superficial features of a work of art, but they fail to understand the underlying and primary notion which these features convey. This leads to many erroneous conclusions.

The purpose of this article is to indicate the necessity of interpreting 
art, too, in its context and with due respect to its primary notion. This will be illustrated by examples of particularly baptismal scenes. It will also be shown how these scenes of art are misused and misinterpreted by modern scholars because the above-mentioned principles are disregarded.

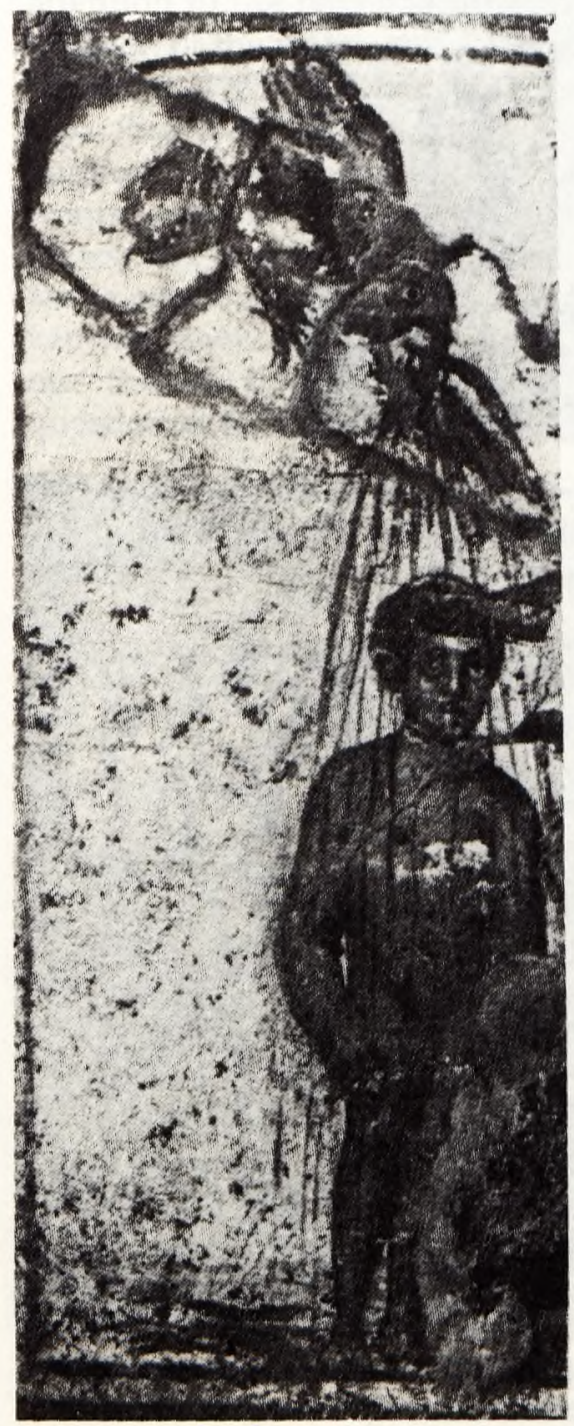

Figure 1: The baptism of Christ. Late third century. Catacomb of Saint Peter and Saint Marcellinus, Rome. Figure 1 is used with permission from Andre Held, Paris. 


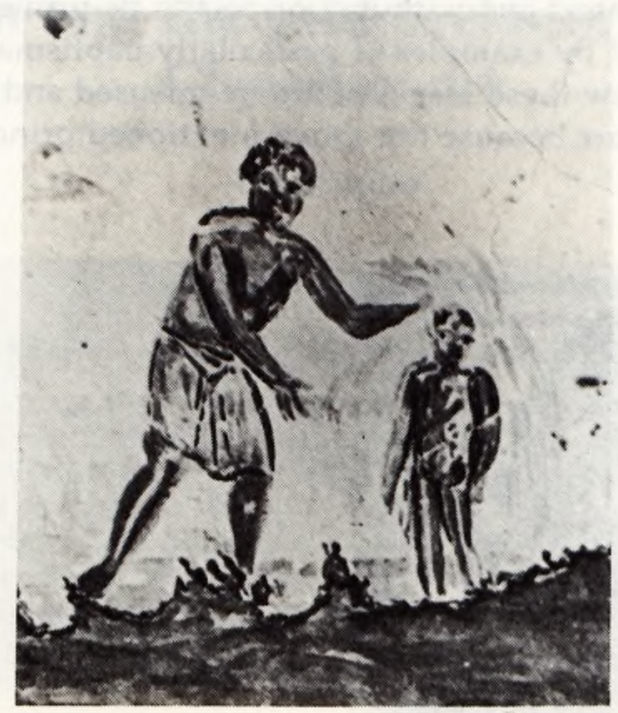

Figure 2: The baptism of Christ. A wall-painting in the catacomb of Calixtus. Third century. Figure 2 is used with permission from Société royale d'archéologie de Bruxelles.

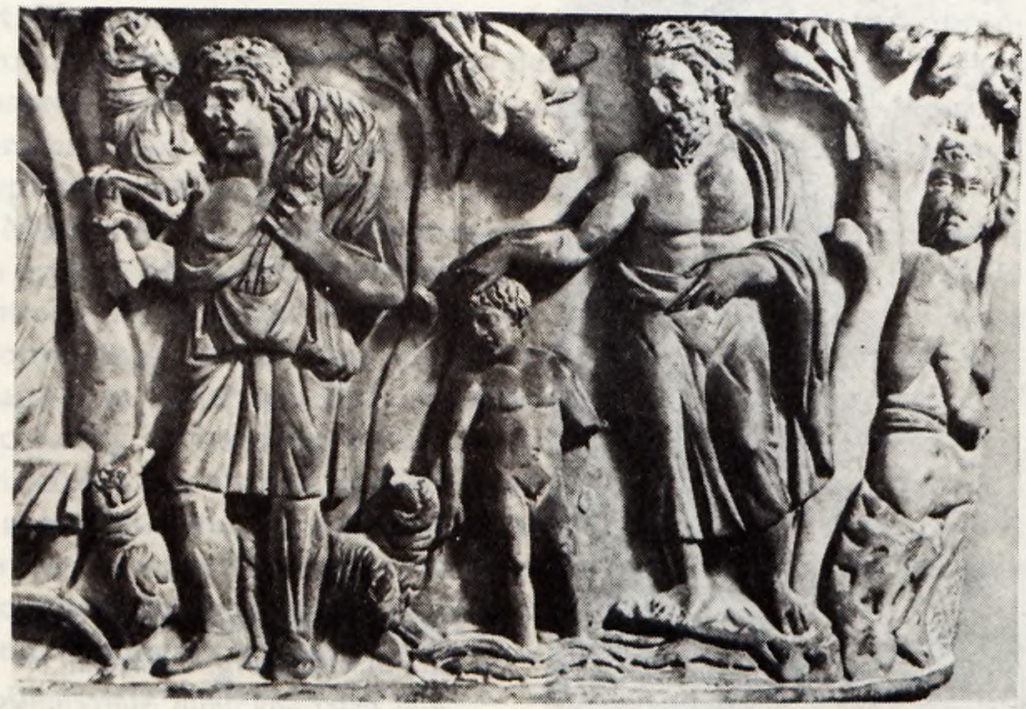

Figure 3: The baptism of Christ. Sarcophagus, Rome. Santa Maria antique. Figure 3 is used with permission from Floris Books (Christian Community Press), London. 
Scholars often appeal to baptismal pictures in the catacomb art to 'prove' that sprinkling was die mode of baptism in the early Church (cf Barnard 1984: 86, Du Preez 1985: 6-9, Floor 1983: 54, Kerr 1944: 79, Oetting 1970: 29, Walker 1970: 88). They then usually refer to depictions such as are shown in Figures 1, 2 and 3.

In their interpretation of scenes such as these, scholars usually draw attention to the boyhood of Jesus (or of the baptismal candidate), the affusion of the water, and the fact that the water is merely ankle deep. Du Preez (1985: 7), for example, who defends the sprinkling of babies, says that these depictions do tell us something about the mode of baptism as practiced in the time of the artist. Möller, on the other hand, wants to account for these depictions, which don't suit his theological views, and thus he says: 'Die feit dat in die onderaardse katakombes te Rome prente is van die besprinkeling in die eerste eeu, sê nog niks. Dit kan nie bewys word dat daardie prente in die eerste eeu geskilder is nie' (Möller 1976: 201). But the dating of these pictures is not the question at issue.

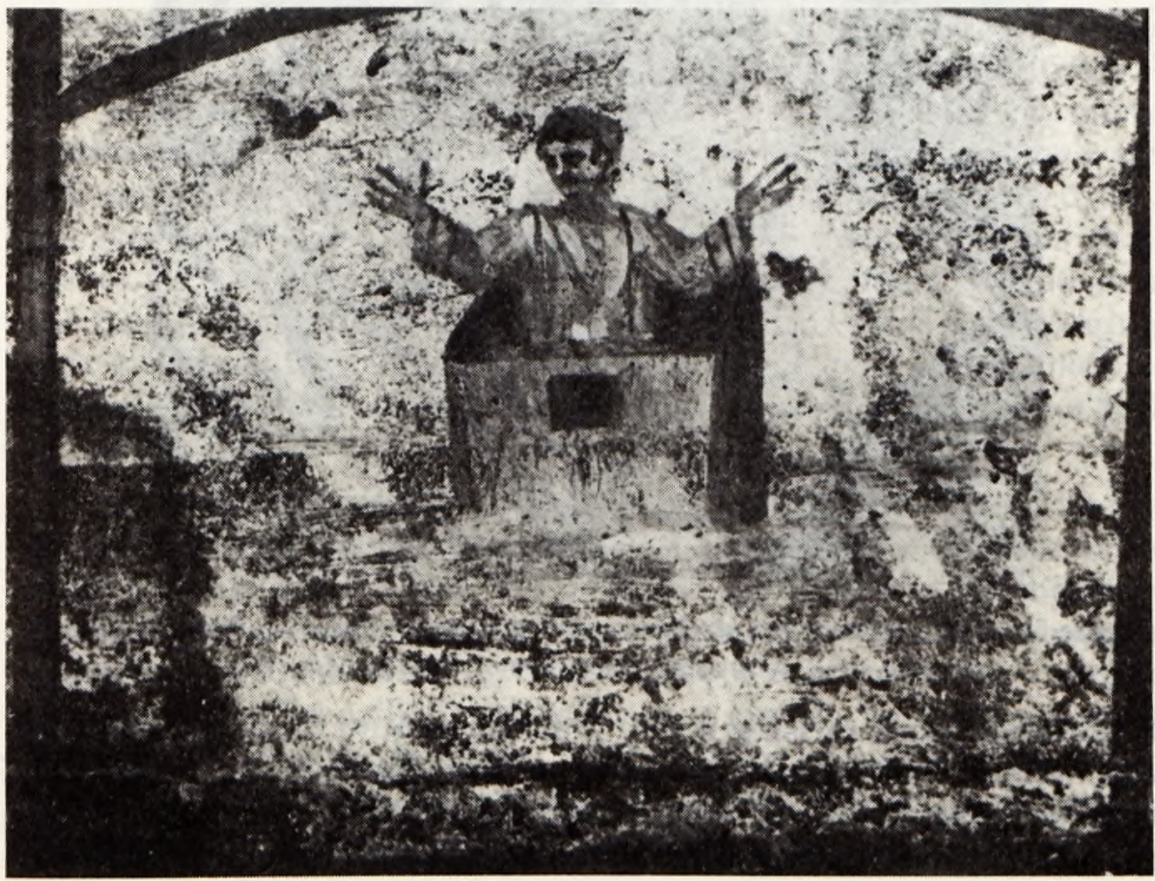

Figure 4: Noah in the ark. Third century. Catacomb of Saint Peter and Saint Marcellinus, Rome. Figure 4 is used with permission from Andre Held, Paris. 


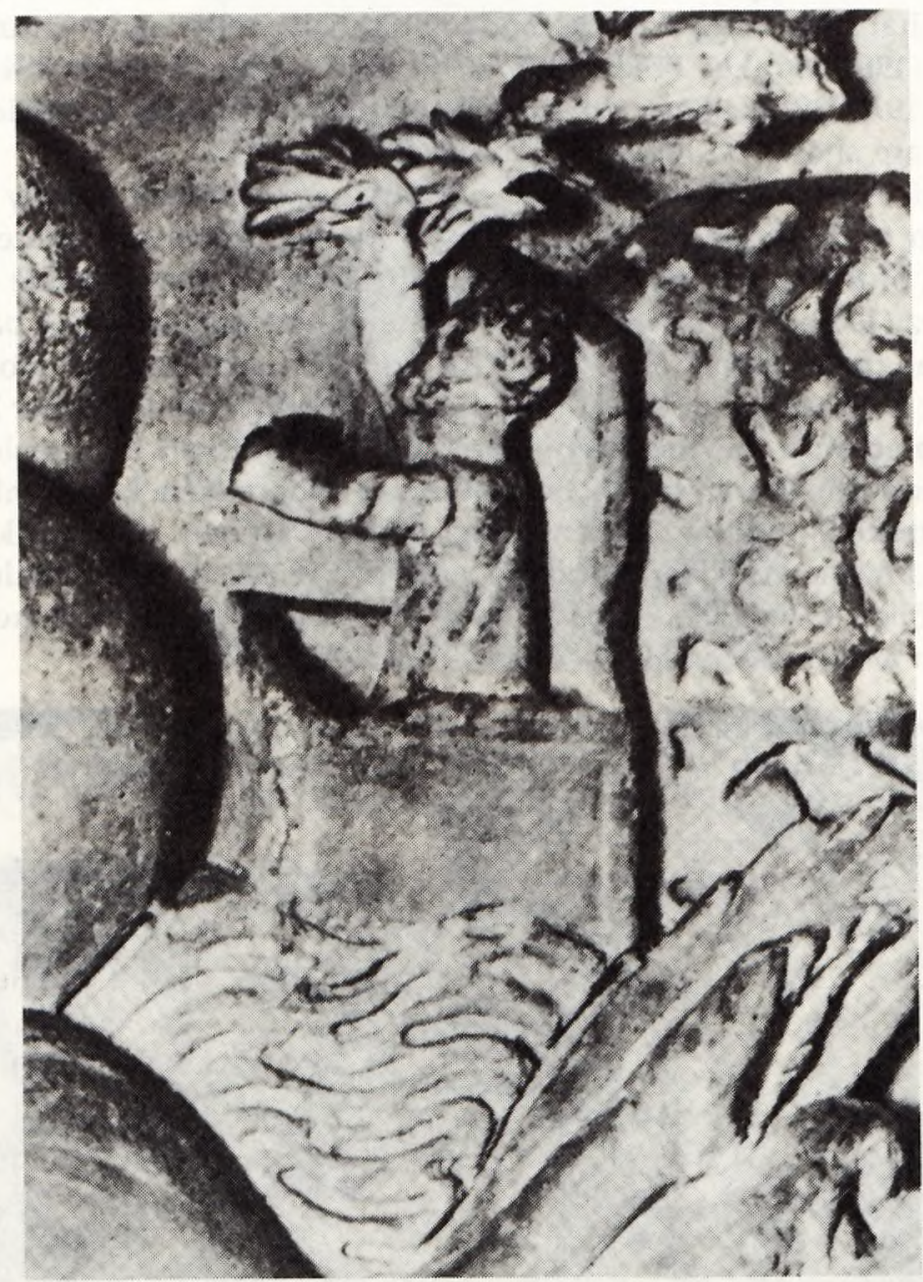

Figure 5: Noah in the ark. Late third century. Lateran museum, Rome. Figure 5 is used with permission from Hirmer Verlag, München.

These scholars are missing a very important point: Early Christian art was neither illustrative or narrative, it was symbolic. To regard any scene as being a pictorial representation of reality is quite risky. It was never the intention of the artist to portray an actual scene, but rather to convey its notion or meaning (deep structure). This very important aspect of early Christian art will become clear when we look at other 
popular Biblical scenes in early Christian art. Let us take, for example, depictions of Noah and the ark, such as is shown in Figures 4 and 5.

There are more than forty depictions of Noah in the ark in the catacombs in Rome alone, dating from $200 \mathrm{AD}$ until the end of the fourth century. All these depictions are very similar: The ark is always a square box, sometimes with little feet. Noah is represented in the posture of an 'orans', sometimes clearly feminine in appearance, standing upright in this boxlike ark. Usually there is also a dove, bearing an olive branch in its beak or in its claws, and it is depicted as flying towards Noah. The ark is never depicted as a three-storey boat, nor are there any animals present. The reason is, of course, that the artist did not intend to illustrate every detail of the story of Noah. He only wanted to convey the meaning which the narrative of Noah and the ark had for him. The saving of Noah from the flood was probably seen as a type of salvation of a believer through baptism, as in 1 Peter 3: 20-21. (For other possible interpretations of the Noah narration in early Christian theology, see the article of Maritz 1983.)

Having realised the symbolic nature of early Christian art, we can now return to the baptismal scenes: The artist is merely portraying all the persons/elements which are present at a baptismal ceremony, namely the one who baptizes, the one who is being baptized, the water and the dove (symbol of the Holy Ghost, which was conferred on a believer at his baptism, according to patristic theology). Thus these scenes do not in any respect bear testimony to the mode of baptism in the time of the artist. If one insists on interpreting the water pouring over the candidate as evidence for sprinkling, one should likewise conclude that baptisms were effected with water coming from the beak of a dove.

Note also that Jesus was depicted as a little boy when He was baptized. This is also contrary to historical facts. As in the case of the water coming from the beak of a dove, the age of Jesus is not the issue. But how then should one explain the relative smallness of the baptismal candidates in the pictorial representations of baptism? It was common practice among the early Christian artists to depict a benefactor as much larger in size than the recipient. Thus when Jesus is depicted as healer, $\mathrm{He}$ is always much larger in size than those who experience his healing. Figures 6 and 7 serve as examples of this.

In Figure 7 Jesus heals the paralytic (middle), a blind man (right) and He raises Lazarus (far right). In Figure 8 Jesus again heals a blind man 


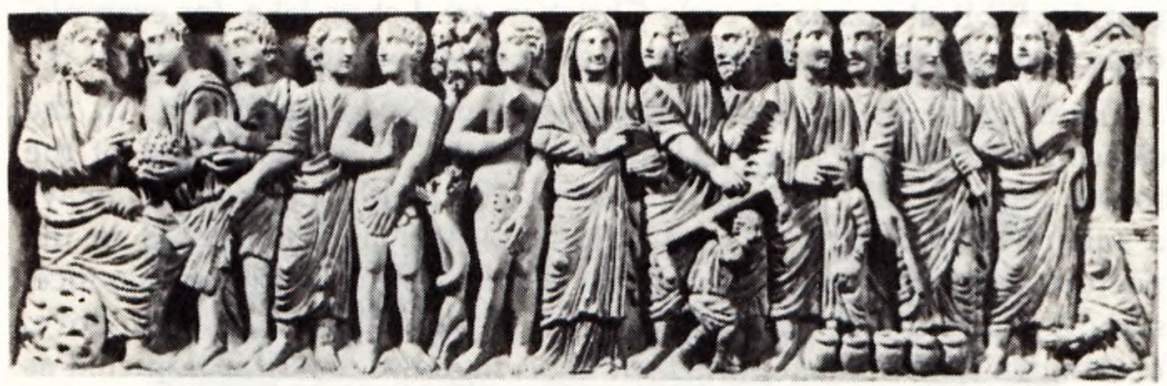

Figure 6: The healing of the paralytic and of the man born blind, the transformation of water into wine and the raising of Lazarus. Sarcophagus, Lateran museum, Rome. Figure 6 is used with permission from Floris Books (Christian Community Press), London.

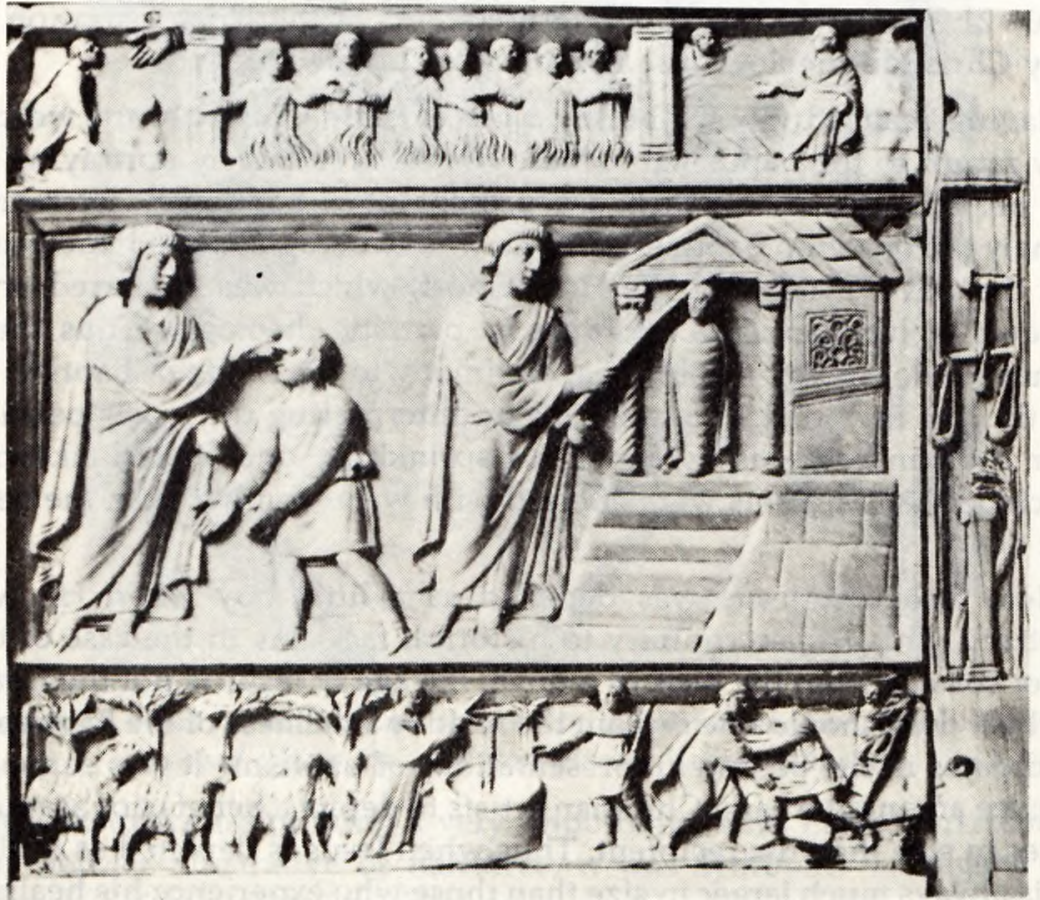

Figure 7: The healing of the blind and the raising of Lazarus. An ivory casket from the Church of Santa Giulia. Second half of the fourth century. Figure 7 is used with permission from Hirmer Verlag, München. 
(left) and raises Lazarus (right). Note the relative smallness of the blind man, the paralytic and Lazarus (the recipients) compared to the size of Jesus (the benefactor). Likewise, the person who baptizes is seen as the benefactor, and the candidate as the recipient.

But when one pleads for the interpretation of art in its context, it must be understood in a very wide sense. When one interprets (say) a verse from the Bible, one should take into consideration not only its place in the pericope, but also its place in the chapter, as well as the place of the chapter in the book as a whole. As a matter of fact, even the place of the book in the Bible as text can contribute to one's interpretation. Similarly, one should not only interpret an art text as a whole, but one should also take note of the place where it is found, as well as its relationship to other scenes in its environment. This principle can be well illustrated by the baptismal scenes which are found in the room of the Dura-Europos house-church on the Euphrates.

One of the rooms in this house, which was enlarged for the use of a Christian congregation, has a baptistry in one corner. Above and alongside the bath there are several wall-paintings. Let us now discuss three of the pictures in this baptismal chamber which have been preserved for us:

In the scene directly above the bath, we see Jesus, depicted as a Good Shepherd, as well as Adam and Eve. Bearing in mind the wider context of this depiction (viz that it is found in a baptismal chamber), the meaning of these portrayals becomes clear. The artist has depicted Adam and Eve because they were responsible for bringing sin into the world. Jesus, depicted as the Good Shepherd, takes away these sins. Thus the underlying notion of this scene is the remission of sins, and specifically, original sin. As is evident from early Christian literature, it was believed that one's sins were removed through baptism. It is quite remarkable that the Church Fathers initially linked baptism to the remission of sins, and not to circumcision.

In the next picture Jesus heals the paralytic. But Jesus is pointing with his hand, and it is clear that $\mathrm{He}$ is saying something. We read in the Gospels that when Jesus healed the paralysed man, He said: 'My son, your sins are forgiven' (Mk 2: 5). Thus the artist again touches upon the theme of the forgiveness of sins, which was linked to baptism. In the third scene we see Jesus stretching out his hand to Peter, who sinks in the waves of the sea. The significance of this scene is the water, which is an important element of baptism. Thus it is clear that all these pictures, found in a baptismal chamber, are carefully selected to 
highlight one aspect or another of baptism. This shows how important it is to interpret art in its wider context.

To conclude: When one interprets any aspect of an art text, one should pay careful attention to its context, setting and deep structure (or underlying notion). A disregard of these principles has led to erroneous conclusions concerning the practice of baptism of the early Christians, as depicted in their art.

\section{Works consulted}

BARNARD, AC 1984. Ek is Gedoop. Pretoria: NG Kerkboekhandel.

DU PREEZ, J 1985. Besprenkeling as Doopvorm? ('n Studie oor die Modus van die Sakrament van die Christelike Doop.) Annale, Universiteit van Stellenbosch. Vol 7, Series B, Nr 1 .

FLOOR, L 1983. Die Heilige Doop in die Nuwe Testament. Noordbrug: Potchefstroomse Teologiese Publikasies.

KERR, HT 1944. The Christian Sacraments. A Source Book for Ministers. Philadelphia: The Westminster Press.

LOUW, JP 1973. Discourse analysis and the Greek New Testament. The Bible Translator. 24, 101-118.

LOUW, JP 1984. Primary and secondary reading of a text. Neotestamentica 18, 18-25.

MARITZ, JA 1983. Noah's ark and the animals of early Christian art. Akroterion, vol 28, nrs 3 \& 4, 102-8.

MÖLLER, FP 1976. Die Sakrament in Gedrang. Braamfontein: Die Evangelie Uitgewers.

OETTING, W 1970. The Church of the Catacombs. St Louis: Concordia Publishing House.

WALKER, W 1970. A History of the Christian Church. Edinburgh: T \& T Clark Ltd. 